\title{
Lepidoptera of Terskij seashore of the Kola Peninsula, Northwestern Russia
}

\author{
Mikhail V. Kozlov \& Jaakko Kullberg
}

Kozlov, M. V. \& Kullberg, J. 2006: Lepidoptera of Terskij seashore of the Kola Peninsula, Northwestern Russia. — Entomol. Fennica 17: 123-129.

The fauna of moths and butterflies of the Western part of the Kola Peninsula is reasonably well documented, while data from Eastern part are scarce, and only five species have so far been recorded from the White Sea shore between Kuzomen and Ponoi. Here we report the results of sampling conducted on June 29-July 2, 2004, in 14 sites along a 150 km stretch between Kuzomen and Pulonga. Among 146 collected species of Lepidoptera, 12 are recorded for the first time from the Kola Peninsula, which increased the regional fauna to 688 species. For Udea nebulalis, which is for the first time reported from Russia, we provide additional records from Karelia.

Mikhail V. Kozlov, Section of Ecology, University of Turku, FI-20014 Turku, Finland;E-mailmikoz@utu.fi

Jaakko Kullberg, Zoological Museum, University of Helsinki, P.O.Box 17, FI00014 Helsinki, Finland; E-mail jkullber@mappi.helsinki.fi

Received 20 April 2005, accepted 2 September 2005

\section{Introduction}

Although the fauna of moths and butterflies of the Kola Peninsula is reasonably well documented, with 676 species reported to date (Kozlov \& Jalava 1994, Kozlov et al. 2000), the vast majority of records originated from the western parts of the Murmansk region. The old Finnish territories were explored before World War II (Valle 1933, Krogerus 1943), while most of the material from the territories adjacent to the railway and road linking Murmansk with Kandalaksha, and from the White Sea shore between Kandalaksha and Varzuga, was accumulated during the past two decades [for a map showing collecting localities, see Kozlov \& Jalava (1994)]. In contrast, the eastern part of the Kola Peninsula is still almost a "blank spot" from where fragmented faunistic data have been collected by Finnish entomologists during the second half of the $19^{\text {th }}$ century and the beginning of the $20^{\text {th }}$ century [see Silfverberg
(1988) for history]. In particular, only five species of Lepidoptera have so far been reported from the White Sea shore between Kuzomen and Ponoi (Kozlov \& Jalava 1994).

Between June 29 and July 2, 2004, 146 species of Lepidoptera were collected in 14 sites along a $150-\mathrm{km}$ stretch between Kuzomen and Pulonga (Fig. 1). This region is difficult to explore, because the roads are suitable only for tracked vehicles. To our knowledge, our team was the first to collect insects in this sparsely populated region since the last visits of the Finnish entomologists in the $19^{\text {th }}$ century. We therefore present a complete list of the Lepidoptera sampled or observed during this visit.

\section{Material and methods}

The habitats surveyed in the course of our excursion were diverse, but we primarily collected in 


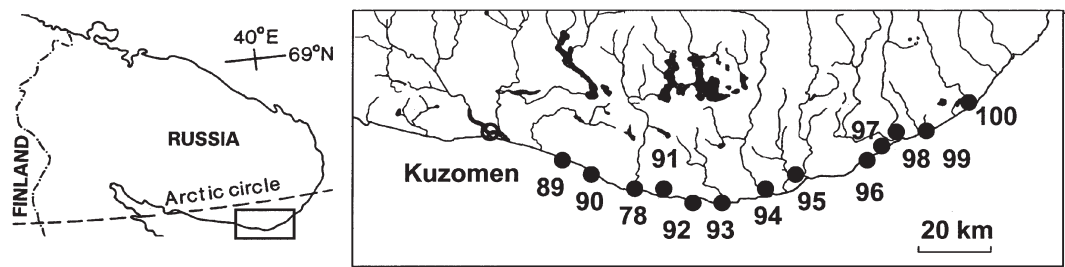

Fig. 1. Location of the sampling sites on the Southern coast of the Kola Peninsula, north-western Russia. Enlarged view shown on right; for place names and coordinates consult Table 1.

stunted birch-dominated forests, birch woodlands, seashore and riverside meadows and tundra-like habitats along the seashore (Fig. 2a-d). Coniferous forest sites occurred in the western part of our route, but further to the East conifers have not been observed near the seashore, although they were sometimes seen near the horizon. Care was taken to survey every possible habitat, although strong winds prevented us from collecting representative materials from several exposed sites. Lepidoptera were only sampled by netting; the total collecting effort approached 40 person-hours. As a rule, the single voucher speci- men had been collected for each species at each study site; however, rare species, as well as groups that are difficult to discriminate in the field, have been collected more thoroughly. We did not aim at estimating abundances of the species, and therefore the numbers of specimens are reported only for species that are rare or new for the Kola Peninsula. Specimens are deposited in the Zoological Museum of the Finnish Museum of Natural History, University of Helsinki (FMNH).

We use the same numeric codes for the localities (Table 1) as in our earlier papers (Kozlov \&
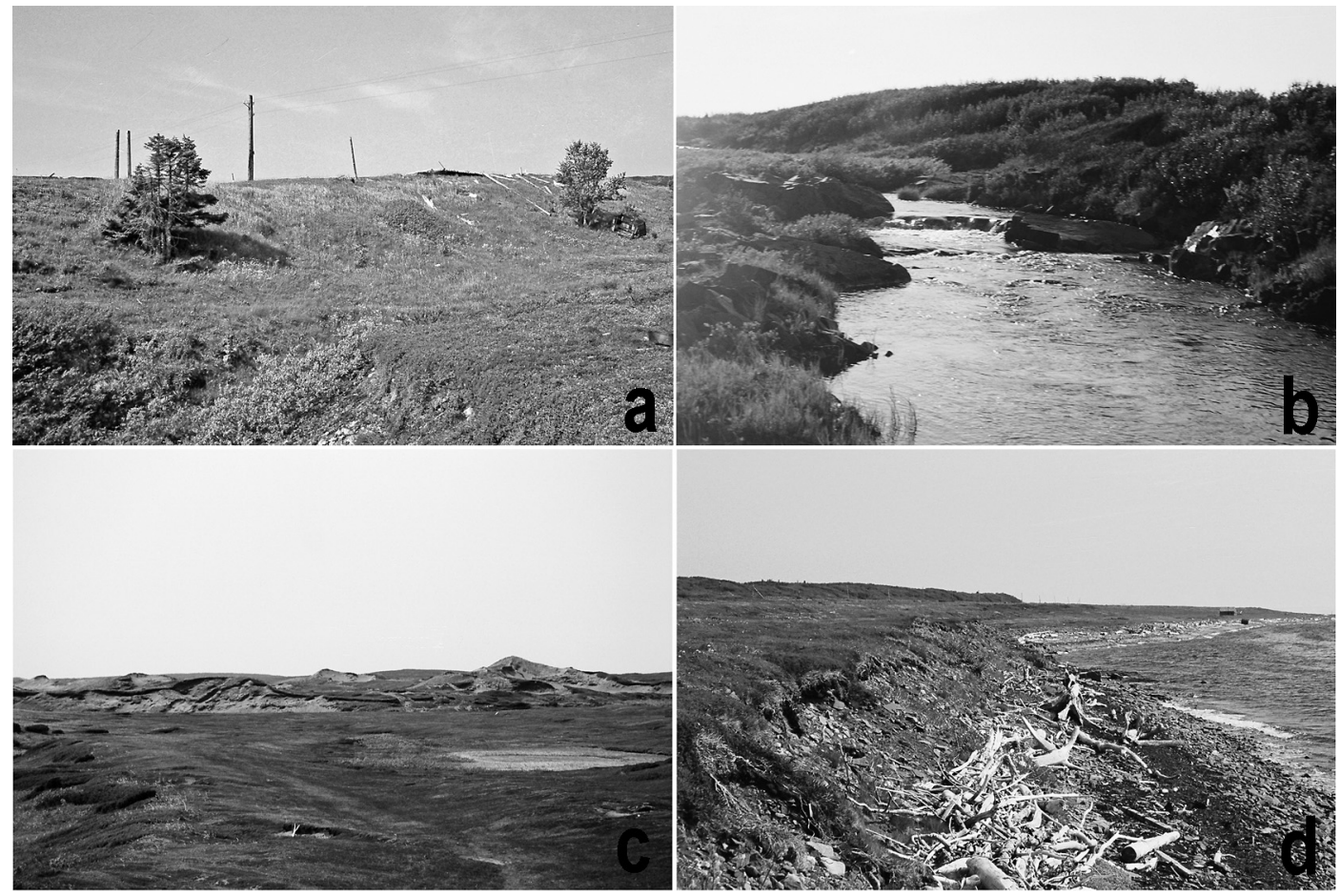

Fig. 2. - a. Seashore near the mouth of Makeevskij River (site 89). - b. Bolshaya Kumuzhya River (site 99). - c. Eroded sand dunes near the mouth of Bolshaya Kumuzhya River (site 99). - d. Seashore East of Chapoma (near the site 96). Photos by V. Zverev. 
Table 1. Waypoints and collecting sites of the expedition along the White Sea shore, Kola Peninsula.

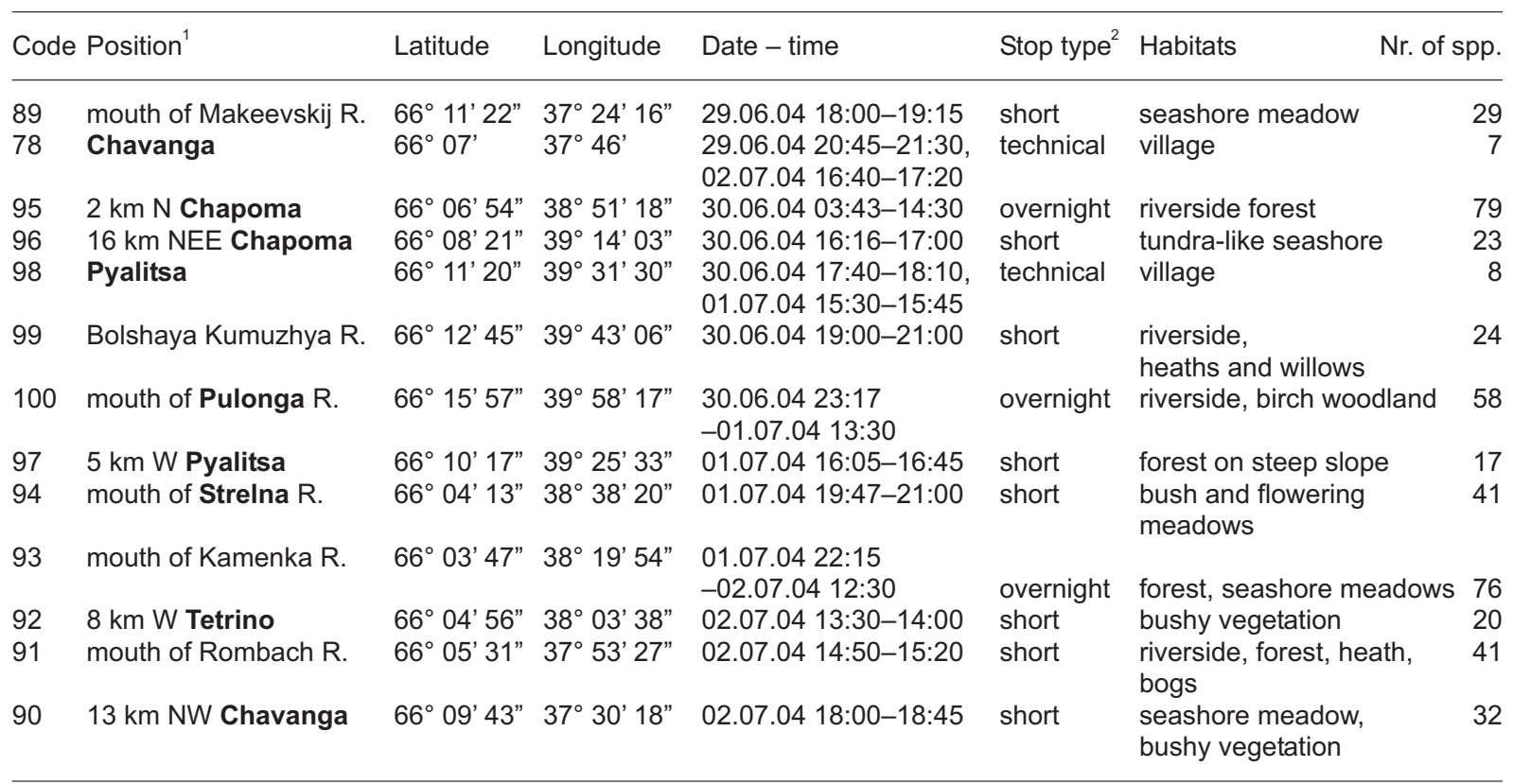

1 Boldfaced are the locality names that can be found in The Times Atlas of the World.

2 Technical stops were made for changing vehicles and for other reasons not related to scientific goals of the excursion, in contrast to other stop s made in habitats most suited for collecting of insects.

Jalava 1994, Kozlov et al. 2000) and add the new localities to the end of the list (numbers 89-100). Taxonomy follows Kullberg et al. (2002); asterisks denote species that have not been previously reported from the Kola Peninsula. For collecting dates consult Table 1. Biogeographical provinces of Finland ( $\mathrm{Le}$, Li, Lkoc, Lkor, Obb, Ks, Oba, Sb, $K b)$ are given in italics; for a map of provinces, consult e. g. Kullberg et al. (2002). UTM grid for the Kola Peninsula was published by Kozlov \& Jalava (1994); UTM grid zones of the World can be found at http://www.dmap.co.uk/utmworld. htm.

\section{List of species}

Micropterigidae

Micropterix aureatella (Scop.). 94, 95, 97, 98.

Nepticulidae

Ectoedemia occultella (L.). 91.

Adelidae

Nematopogon swammerdamellus (L.). 95.
Nemophora bellela (Wlk.). 91.

Incurvariidae

Phylloporia bistrigella (Hw.). 100.

Incurvaria oehlmanniella (Hb.). 91, 95.

Incurvaria vetulella (Zett.). 91.

Incurvaria circulella (Zett.). 93, 95.

Prodoxidae

*Lampronia standfussiella (Z.). 93: 2 exx. A rare species living on Rosa majalis Herrm., usually occurring on river meadows and sandy places. In Northern Europe, this species was known only from the vicinity of Petrozavodsk, until it was discovered in 1994 in Finland in the vicinity of Rovaniemi, $O b b$ (Itämies et al. 1996); in 2004 it was also found in Sweden on an island in the Tornionjoki River (N. Ryrholm, pers. comm.).

Tineidae

Myrmecozela ochraceella (Tengstr.). 95.

Gracillariidae

Callisto coffeella (Zett.). 97. 
Phyllonorycter hilarellus (Zett.). 95, 99.

Yponomeutidae

Paraswammerdamia conspersella (Tengstr.). 95.

Argyresthiidae

Argyresthia conjugella Z. 99.

Plutellidae

Plutella xylostella(L.). 89, 90, 92, 93, 94, 95, 96, 99, 100.

Oecophoridae

Pleurota bicostella (Cl.). 89, 91, 92.

Denisia stipella (L.). 90.

Elachistidae

Elachista diederichsiella E. Hering. 94.

Elachista nobilella Z. 89, 93.

Elachista apicipunctella Stt. 89, 95.

Elachista subalbidella Schl. 89, 95.

Cosmiotes freyerella (Hb.). 89.

Coleophoridae

Coleophora lusciniaepennella (Tr.). 98.

Coleophora alticolella Z. 93.

Coleophora virgaureae Stt. 94.

Coleophora saxicolella (Dup.). 93.

Coleophora atriplicis Meyr. 93.

Coleophora trochilella (Dup.). 100.

Coleophora striatipennella Nylander. 89, 93, 95, 100.

\section{Momphidae}

Mompha raschkiella (Z.). 93.

*Mompha sturnipennella (Tr.). 93: 1 ex. The northernmost record for Russia; so far, was known from Arkhangelsk and Petrozavodsk (S. Sinev, pers. comm.) and from the Krasnyi Kamen in Polar Ural near the Arctic Circle (J. Kullberg, pers. obs.). The species is occurring in Finland up to the northernmost province $\mathrm{Li}$ (Kullberg et al. 2002).

Gelechiidae

*Xystophora pulveratella (H.-S.). 93: 1 ex. One of the northernmost records for this species; in Finland, occurs in $K s$ and southwards (Kullberg et al. 2002). This species is considered common in most of its range in Finland, and was to be expected in the Kola Peninsula. The larva feeds on several legume species e.g. Vicia cracca L., Lathyrus pratensis L. and Medigaco spp. (Kaitila 1996).

*Monochroa saltenella (Benander). 95: 2 exx. Very uncommon species; in Finland, recorded once in Kilpisjärvi, Le (Kullberg et al. 2002). The species is relatively widespread, but rarely collected in the Scandinavian mountains (Aarvik et al. 2000; Gustafsson 2004). In Russia, it has only been collected in the Polar Ural and the Altai mountains (Karsholt 2004, J. Kullberg, pers. obs.). The biology is unknown, but Rumex acetosa L. is supposed to be the food plant (Svensson 1993). Specimens have been found in wet meadows in the Polar Ural at $250 \mathrm{~m}$ a.s.1. (J. Kullberg, pers. obs.), and in mountain meadows in Scandinavia - mainly in the birch zone (Gustafsson 2004). On the Kola Peninsula, specimens were collected from riverside vegetation at about sea level.

Bryotropha galbanella (Z.). 93.

* Bryotropha senectella (Z.). 94: 1 ex. The northernmost record for this species; in Finland, it occurs in $S b, K s$ and $K b$ and southwards (Kullberg et al. 2002, 2005; Karsholt \& Rutten 2005). A species living in moss; and may be easily overlooked in the north.

Teleiodes proximella (Hb.). 90, 91, 93.

Teleiopsis diffinis (Hw.). 100.

Chionodes viduella (F.). 96, 98.

Lita sexpunctella (F.). 78, 95.

* Gnorimoschema epithymellum (Stgr.). 93: 1 ex. Expected species that occurs on sandy and rocky places northwards up to Lkoc and Lkor in Finnish Lapland. In northern Europe it is represented by ssp. brunneomaculellum (Hackman, 1946). In Finland, the food plant is Solidago (Kaitila 1996), possibly also Erigeron (J. Kullberg, pers. obs.).

Scrobipalpa murinella (Dup.). 95.

Scrobipalpa obsoletella (F.R.). 93.

Scrobipalpa atriplicella (F.R.). 93, 100.

Tortricidae

Choristoneura albaniana (Wlk.). 95.

Syndemis musculana (Hb.). 95.

Clepsis senecionana (Hb.). 93, 94, 95, 100.

Clepsis rogana (Gn.). 89, 90, 91, 92, 93, 94, 95, 
100. The populations of both the Kola Peninsula and the Polar Ural differ from those in central Europe and southeast Finland (Kullberg et al. 2002) by their smaller size and darker coloration.

Eulia ministrana (L.). 91, 95, 99, 100.

Trachysmia vulneratana (Zett.). 93.

Aethes deutschiana (Zett.). 95, 99, 100.

Aethes triangulana (Tr.). 92, 95.

Aethes smeathmanniana (F.). 78, 93, 95.

Cochylidia subroseana (Hw.). 93, 94, 95, 100.

Cochylis dubitana (Hb.). 93, 95.

Celypha cespitana (Hb.). 91.

Olethreutes ledianus (L.). 91, 96.

Olethreutes obsoletanus (Zett.). 90, 94, 95, 100.

Olethreutes lacunanus (Den. et Schiff.). 93, 94, 95, 100.

Olethreutes bipunctanus (F.). 90, 91, 93.

Olethreutes metallicanus (Hb.). 93, 94, 95.

Olethreutes schulzianus (F.). 91, 92, 93, 95, 96, 97, 99, 100.

Olethreutes septentrionana (Curt.). 90.

Hedya atropunctana (Zett.). 90, 96, 99, 100.

Apotomis sauciana (Fröl.). 91.

Apotomis demissana (Kenn.). 100.

Ancylis comptana (Fröl.). 93, 95.

Ancylis unguicella (L.). 78, 90, 91, 93, 95, 99, 100.

*Ancylis diminutana (Hw.) 100: 2 exx. The northernmost record for this species, but expected because the species occurs in Finland up to Oba province (Kullberg et al. 2002).

Ancylis subarcuana (Douglas). 93, 99.

Ancylis badiana (Den. et Schiff.). 95, 97.

Ancylis myrtillana (Tr.). 91, 95, 96, 97, 100.

Epinotia subocellana (Don.). 90, 91, 93, 94, 97.

Epinotia tetraquetrana (Hw.). 93, 94, 95, 96, 97, 98, 99, 100.

Epinotia nemorivaga (Tengstr.). 99.

Eriopsela quadrana (Hb.). 95, 100.

Eucosma guentheri (Tengstr.). 93.

Eucosma aspidiscana (Hb.). 93, 94, 95, 96.

Pammene clanculana (Tengstr.). 99.

Pammene aurana (F.). 89, 90.

*Cydia nigricana (F.). 89: 1 ex. The northernmost record: in Russia, previously known from Petrozavodsk (Danilevskij \& Kuznetsov 1968). In Finland, reported from $O b a$ province and southwards (Kullberg et al. 2002).
Cydia indivisa (Danil.). 90, 95. Previously known from one specimen collected near Monchegorsk (Kozlov et al. 2000).

Cydia orobana (Tr.). 89, 90.

Cydia aureolana (Tengstr.). 89, 90, 91, 93, 94, 95, 97, 100.

Dichrorampha cinerascens (Danil.). 89, 90, 93, 95.

Sesiidae

*Synanthedon polaris (Stgr.). 91: 1 ex., 92: 1 ex. A northern species widely distributed in neighbouring areas westward (Kullberg et al. 2002).

Pterophoridae

Amblyptilia punctidactyla (Hw.). 95, 100.

Platyptilia calodactyla (Den. et Schiff.). 94.

Platyptilia pallidactyla (Hw.). 94.

Leioptilus osteodactylus (Z.). 93, 95, 100.

Pyralidae

Polopeustis altensis (Wck.). 89, 90, 92, 93, 95, 96, 98, 99, 100.

Crambus ericellus (Hb.). 93.

*Crambus heringiellus H.-S. 95: 1 ex. The nearest records from the southern provinces of Finnish Lapland: Lkoc and Lkor (Kullberg et al. 2002).

Crambus lathoniellus (Zinck.). 78, 89, 90, 91, 93, 94, 95.

Crambus perlellus (Scop.). 91.

Gesneria centuriella (Den. et Schiff.). 95.

Eudonia alpina (Curt.). 95, 99.

*Evergestis aenealis (Den. et Schiff.). 90: 2 exx. One of the northernmost records for this species; in Finland, reported from province $L$ kor and then in $\mathrm{Oba}$ and southwards (Kullberg et al. 2002). The species seems to be expanding northwards recently.

Pyrausta porphyralis (Den. et Schiff.). 78, 93, 95.

Loxostege commixtalis (Walker). 95.

Algedonia terrealis (Tr.). 91, 93.

Anania funebris (Ström). 90, 91, 92, 93, 94, 95, 96, 100.

Opsibotys fuscalis (Den. et Schiff.). 89, 90, 93, 94, 95.

*Udea nebulalis (Hb.). 94: 1 ex. Likely the first reliable record for Russia; so far, only doubtful records from Southern Russia have been 
available (Nuss et al. 2004). However, the species had long been known to occur in Russia, although the following old records from the FMNH collection (total of 25 exx.) have not been previously published: St. Petersburg region: Sosnovo (Rautu), Solnetshnoje (Ollila), Gogland (Suursaari), Bol'shoi Tyuters (Tytärsaari); Republic of Karelia: Lahdenpohja, Harlu, Impilahti, Kirjavalahti, Petrozavodsk, Tiudia (Tiuti) near Kondopoga (Kontupohja), Kosmozero (Kuosmajärvi) north of Petrozavodsk. In Finland, this species has been reported from the province $K s$ and southwards (Kullberg et al. 2002).

Udea decrepitalis (H.-S.). 91, 92, 93, 94, 95, 97, 100.

Zygaenidae

Zygaena exulans (Hochenw.). One specimen observed by V. Zverev between 95 and 96 .

Pieridae

Aporia crataegi (L.). 100 (visual observation by

S. Koponen); also collected in Kandalaksha (60) on 4.VII.2004 by L. Huldén (pers. comm.).

Pieris napi (L.). 94, 96, 97, 98.

Lycaenidae

Callophrys rubi (L.). 91, 95.

Lycaena phlaeas (L.). 89.

Vacciniina optilete (Knoch). 89, 90, 91, 92.

Nymphalidae

Vanessa cardui (L.). 89, 92, 93, 95.

Aglais urticae (L.). 89, 90, 93.

Clossiana freija (Thnbg.). 96.

Clossiana euphrosyne (L.). 90, 91, 92, 93, 94, 95, 96.

Drepanidae

Falcaria lacertinaria (L.). 93, 100.

Drepana falcataria (L.). 95.

Geometridae

Jodis putata (L.). 90, 91, 93, 95, 99.

Cyclophora albipunctata (Hufn.). 90, 92, 93.

Scopula ternata (Schrank). 93, 95.

Xanthorhoe munitata (Hb.). 100.

Xanthorhoe spadicearia (Den. et Schiff.). 93, 94, $95,100$.
Xanthorhoe ferrugata (Cl.). 93, 94, 95, 100.

Xanthorhoe montanata (Den. et Schiff.). 89, 93, 94, 95, 97.

Epirrhoe alternata (Müll.). 93, 94, 97, 100.

Colostygia turbata (Hb.). 94.

Hydriomena impluviata (Den. et Schiff.). 93, 100.

Hydriomena ruberata (Freyer). 95.

Rheumaptera hastata (L.). 100.

Epirrita autumnata (Bkh.). 78, 91, 93, 97, 100

(all records based on larvae).

Perizoma affinitatum (Stph.). 89, 91, 93, 94.

Perizoma blandiatum (Den. et Schiff.). 78, 89, 90, 94, 96, 100.

Eupithecia pygmaeata (Hb.). 93, 99.

Eupithecia satyrata (Hb.). 91, 93, 94, 95, 96, 100.

Eupithecia vulgata (Hw.). 91, 93, 95.

Eupithecia gelidata Möschl. 93, 94.

Eupithecia virgaureata Doubl. 91, 93, 97, 100.

Lomaspilis marginata (L.). 95.

Ematurga atomaria (L.). 90, 92, 93, 95, 96, 97, 98, 99, 100 .

Cabera exanthemata (Scop.). 91.

Parietaria vittaria (Thnbg.). 92, 100.

Arctiidae

Diacrisia sannio (L.). 90 (common). Previously reported from the Kola Peninsula on the basis of two specimens collected between Umba and Kandalaksha (Kozlov \& Jalava 1994).

Phragmatobia fuliginosa (L.). 94.

Noctuidae

Polypogon tentacularius (L.). 91, 92, 93, 94, 95, 98.

Euclidia glyphica (L.). 94.

Syngrapha hochenwarthi (Hochenw.). 100.

Acronicta auricoma (Den. et Schiff.). 93.

Hyppa rectilinea (Esp.). 100.

\section{Discussion}

Contrary to our expectations, we did not collect any species characteristic of the eastern part of the European North. The fauna of the explored habitats resembles that of the more western part of the White Sea shore between Umba and Varsuga. All species new for the Kola Peninsula are characteristic of the boreal zone, except for Monochroa 
saltenella that merely belongs to the subarctic meadows. Interestingly, some of the species that have recently been discovered in the Kola Peninsula may be expanding northward over the past decades: they have been recorded in Northern Finland only recently (Kullberg et al. 2002).

Summarizing our records for three UTM grid cells (approx. $50 \mathrm{~km} \times 50 \mathrm{~km}$ ) visited in the course of our excursion, we found 43 species in DP2 (sites 78, 89, 90), which increased the total number of species in this grid cell from 5 to 48 ; 119 species in DP4 (sites 91-95) in addition to the three species recorded earlier, and 65 species in EP2 (sites 96-100), from which no Lepidoptera have been reported earlier (Kozlov \& Jalava 1994). The low number of species recorded in DP2 results from low collecting effort (we focused on sampling the most distant localities).

Although our data are not strong enough to make quantitative assessments of the diversity of Lepidoptera in the surveyed sites, the general impression is that the diversity declines from West to East, with the lowest number of species (adjusted for sampling effort) recorded in Pulonga: some 12 person-hours of collecting brought only 58 species, while 1.5 person-hours in the mouth of Rambach River resulted in sampling 41 species (Table 1). This is most likely explained by an overall decrease in habitat diversity, in particular by the absence of conifers and other plants associated with taiga forests.

The knowledge on the fauna of moths and butterflies of the Kola Peninsula, with 688 species recorded so far, is now at about the same level as that of Northern Fennoscandia, with 602 species listed by Linnaluoto \& Koponen (1980). However, comparison with the mentioned study and with recent Finnish catalogue (Kullberg et al. 2002) suggests that some 50-80 additional species are almost certainly to be found in the Kola Peninsula.

Acknowledgements. We thank E. Melnikov and V. Zverev for collecting of Lepidoptera, S. Koponen and L. Huldén for sharing data on species that they have observed or collected during this excursion, V. Lavrits for numerous practical arrangements, and local resident Alexey for safe driving of the army truck and tracked tank. We want to express our gratitude to L. Kaila, V. Mironov and S. Sinev for identification of difficult taxa and providing useful information on species distribution, and to C. Schmidt for commenting an earlier draft of the manuscript. The travel was partially supported by the Universities of Joensuu and Turku, Finland.

\section{References}

Aarvik, L., Berggren, K. \& Hansen, L. O. 2000: Catalogus Lepidopterorum Norvegiae. - Lepidopterologisk Arbeidsgruppe, Oslo. 192 p.

Danilevskij, A. S. \& Kuznetsov, V. I. 1968: Leaf-rollers Tortricidae. Seedworms - Laspeyresiini. Fauna of U.S.S.R. Lepidoptera. Vol. 5, pt. 1. — Nauka, Leningrad. 636 p. [In Russian.]

Gustafsson, B. 2004: Svenska fjärilar. — http://www2. nrm.se/en/svenska_fjarilar/svenska_fjarilar.html (Access date 5 May 2004).

Itämies, J., Mutanen, M. \& Mutanen, T. 1996: Lampronia standfussiella (Zeller, 1839) (Lepidoptera: Prodoxidae), Suomelle uusi pikkuperhoslaji. — Baptria 21: 119-121.

Kaitila, J.-P. 1996: Suomen jäytäjäkoiden (Gelechiidae) elintavat. - Baptria 21: 81-105.

Karsholt, O. 2004: Gelechiidae. — In: Karsholt, O. \& Nieukerken, E. J. van (eds.), Lepidoptera, Moths. Fauna Europaea version 1.1. Availalbe at http://www. faunaeur.org

Karsholt, O. \& Rutten, T. 2005: The genus Bryotropha Heinemann in the western Palaearctic (Lepidoptera: Gelechiidae). — Tijdschrift voor Entomologie 148: 77207.

Kozlov, M. V. \& Jalava, J. 1994: Lepidoptera of Kola Peninsula, northwestern Russia. — Entomol. Fennica 5: 6585.

Kozlov, M. V., Jalava, J. \& Shutova, E. 2000: New records of Lepidoptera from the Kola Peninsula, Northwestern Russia. - Entomol. Fennica 11: 131-136.

Krogerus, H. 1943: Lepidopterologiska studier i södra Petsamo. - Notulae Entomol. 23: 19-43.

Kullberg, J., Albrecht, A., Kaila, L. \& Varis, V. 2002: Checklist of Finnish Lepidoptera - Suomen perhosten luettelo. - Sahlbergia 6: 45-190.

Kullberg, J., Albrecht, A., Kaila, L. \& Varis, V. 2005: Checklist of Finnish Lepidoptera - Suomen perhosten luettelo. — http://www.fmnh.helsinki.fi/elainmuseo/ hyonteiset/perhoset/index.htm (Access date 12 April 2005).

Linnaluoto, E. T. \& Koponen, S. 1980: Lepidoptera of Utsjoki, northernmost Finland. - Kevo notes 5: 1-68.

Nuss, M., Speidel, W. \& Segerer, A. 2004. Pyralidae. - In: Karsholt, O. \& Nieukerken, E. J. van (eds.), Lepidoptera, Moths. Fauna Europaea version 1.1. Available at http://www.faunaeur.org

Silfverberg, H. 1988: Finnish entomologists on the Kola Peninsula. - Notulae Entomol. 68: 115-120.

Svensson, I. 1993: Fjärilkalender (Lepidoptera-calendar). - H. Hellberg, Kristianstad. 124 pp.

Valle, K.J. 1933: Die Lepidopterenfauna des Petsamogebietes under faunistisch-zoogeographischer Berücksichtigung der Fauna ganz N-Fennoscandias. Ann. Zool. Soc. "Vanamo". 1(3): 1-262. 